\title{
Characteristics of Al-Si Alloys with High Melting Point Elements for High Pressure Die Casting
}

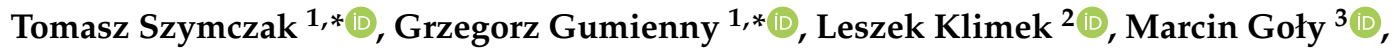 \\ Jan Szymszal ${ }^{4}$ and Tadeusz Pacyniak ${ }^{1}$ \\ 1 Department of Materials Engineering and Production Systems, Lodz University of Technology, \\ 90-924 Lodz, Poland; tadeusz.pacyniak@p.lodz.pl \\ 2 Institute of Materials Science and Engineering, Lodz University of Technology, 90-924 Lodz, Poland; \\ leszek.klimek@p.lodz.pl \\ 3 Department of Physical \& Powder Metallurgy, AGH University of Science and Technology, \\ 30-059 Krakow, Poland; marcing@agh.edu.pl \\ 4 Department of Technical Sciences and Management, University of Occupational Safety Management \\ in Katowice, 40-007 Katowice, Poland; jszymszal@wszop.edu.pl \\ * Correspondence: tomasz.szymczak@p.lodz.pl (T.S.); grzegorz.gumienny@p.lodz.pl (G.G.); \\ Tel.: +48-426312276 (T.S.); +48-426312264 (G.G.)
}

Received: 9 October 2020; Accepted: 29 October 2020; Published: 29 October 2020 updates

\begin{abstract}
This paper is devoted to the possibility of increasing the mechanical properties (tensile strength, yield strength, elongation and hardness) of high pressure die casting (HPDC) hypoeutectic Al-Si alloys by high melting point elements: chromium, molybdenum, vanadium and tungsten. EN AC-46000 alloy was used as a base alloy. The paper presents the effect of $\mathrm{Cr}, \mathrm{Mo}, \mathrm{V}$ and $\mathrm{W}$ on the crystallization process and the microstructure of HPDC aluminum alloy as well as an alloy from the shell mold. Thermal and derivative analysis was used to study the crystallization process. The possibility of increasing the mechanical properties of HPDC hypoeutectic alloy by addition of high-melting point elements has been demonstrated.
\end{abstract}

Keywords: crystallization; microstructure; mechanical properties; thermal and derivative analysis

\section{Introduction}

High melting point elements, such as $\mathrm{Cr}, \mathrm{Mo}, \mathrm{V}$ and $\mathrm{W}$ are rarely used as additions in Al-Si alloys. Research papers described two main reasons for using these additions in Al-Si alloys. The first reason is the enhancement of the precipitation hardening effect [1-4] while the second one is a reduction of the detrimental effect of iron on mechanical properties [4-9]. However, the use of $\mathrm{Cr}, \mathrm{Mo}, \mathrm{V}$ and $\mathrm{W}$ in Al-Si alloys is very limited considering the nature of their interaction with the main alloy constituents, i.e., $\mathrm{Al}$ and Si. The phase diagrams Al-Cr [10,11], Al-Mo [12], Al-V [11] and Al-W [11] show the lack of solubility or very limited solubility of high-melting point elements in aluminum. According to [10], $\mathrm{Cr}$ is not soluble in $\mathrm{Al}$, while according to [11], the solubility of $\mathrm{Cr}$ in $\mathrm{Al}$ is negligible and amounts to $0.71 \mathrm{wt} \%$ at $661.5^{\circ} \mathrm{C}$. Tungsten is not soluble in $\mathrm{Al} \mathrm{[11].} \mathrm{Similar} \mathrm{behavior} \mathrm{shows} \mathrm{molybdenum} \mathrm{[11,12],}$ while the solubility of vanadium in aluminum is maximum $0.6 \mathrm{wt} \%(0.3$ at \%) [11]. Very limited solubility of the above-mentioned elements in aluminum causes the precipitation of a number of intermetallic phases. Also, Si-V [13], Cr-Si [11], Mo-Si [14] and W-Si [15] phase diagrams show that the tested elements practically do not dissolve in silicon. In accordance with these phase diagrams, $\mathrm{Cr}$, Mo, $\mathrm{V}$ and $\mathrm{W}$ also tend to form numerous intermetallic phases with silicon. For example, four intermetallic phases can occur in the $\mathrm{Si}-\mathrm{V}$ diagram, i.e., $\mathrm{SiV}_{3}, \mathrm{Si}_{3} \mathrm{~V}_{5}, \mathrm{Si}_{5} \mathrm{~V}_{6}$ and $\mathrm{Si}_{2} \mathrm{~V}$ [13]. On the other hand, the analyzed elements offer excellent mutual solid-state solubility. Cr-Mo, Cr-V, Mo-V, Mo-W and V-W 
phase diagrams presented in [11,16-19] show that they form unlimited solutions. In [20], Cr-W phase diagram has been described. It shows that $\mathrm{Cr}$ and $\mathrm{W}$ form a solid solution $(\alpha \mathrm{Cr}, \mathrm{W})$ with unlimited mutual solubility of both elements. At $1677^{\circ} \mathrm{C}$, it decomposes into two solid solutions $(\alpha 1)$-rich in chromium and $(\alpha 2)$-rich in tungsten.

The presented data show that in Al-Si alloys containing Cr, Mo, V and $\mathrm{W}$, intermetallic phases with $\mathrm{Al}$ and/or $\mathrm{Si}$ can crystallize. In multicomponent Al-Si alloys, the possibility of the formation of more complex phases containing other constituents, like $\mathrm{Cu}, \mathrm{Mg}$ or $\mathrm{Ni}$ should be taken into account. Intermetallic phases can significantly increase the brittleness of $\mathrm{Al}$ alloys and reduce their strength and elongation. The risk of the precipitation of intermetallic phases in aluminum alloys containing $\mathrm{Cr}, \mathrm{Mo}, \mathrm{V}$ and $\mathrm{W}$ increases with the decreasing rate of heat transfer from the casting. Therefore, these additives are not applicable to Al-Si alloys produced in sand and ceramic molds. Additionally, in the case of hypoeutectic alloys, the formation of intermetallic phases in a higher temperature than the temperature of $\alpha(\mathrm{Al})$ phase crystallization changes the additives concentration ahead of the dendritic crystallization front. As a consequence of the high heat transfer during solidification in metal molds, the $\alpha(\mathrm{Al})$ phase can be supersaturated with high-melting point elements. High pressure die casting (HPDC) is a technology widely used in industry and characterized by intensive heat transfer from the casting. Therefore, in relation to hypoeutectic aluminum alloys containing $\mathrm{Cr}, \mathrm{Mo}, \mathrm{V}$ and $\mathrm{W}$, precisely this technology should be seen as an opportunity to effectively increase the mechanical properties of castings made from the above mentioned alloys. The possibility of increasing the properties of HPDC Al-Si alloy by supersaturation of $\alpha(\mathrm{Al})$ phase with high melting point elements is the most innovative aspect of this paper.

The aim of the paper is to confront the phenomena occurring during the crystallization of Al-Si alloy with different content of high-melting point elements with their mechanical properties in the context of developing the probable mechanism of changes in the properties of the alloy. The crystallization process was investigated by thermal and derivative analysis. Optical and scanning microscopy were used to study the alloy microstructure. A point analysis of the chemical composition of selected phases in the microstructure was also performed with the use of an EDS (Energy Dispersive Spectroscopy) detector. The static tensile test and the Brinell hardness test were used to determine the mechanical properties

\section{Materials and Methods}

A typical hypoeutectic Al-Si alloy for high pressure die casting, i.e., EN-AC 46000 (EN-AC AlSi9Cu3 $(\mathrm{Fe})$ ), was used for the tests. It is included in the PN-EN 1706 standard. The chemical composition of the base alloy is shown in Table 1. The range of the chemical composition is derived from 15 specimens of the base alloy. The reason for such a number of specimens is the testing of 15 different combinations of high melting point elements. The number of $\mathrm{Cr}, \mathrm{Mo}, \mathrm{V}$ and $\mathrm{W}$ combinations means all statistically possible connections that can be used for the four analyzed elements. Therefore, each time new base alloy was smelted from ingots of EN AC-46000 alloy. The individual connections Cr, Mo, V and W have been shown in the following description of a melting technology.

Table 1. Chemical composition of the base EN AC-46000 alloy.

\begin{tabular}{cccccccccc}
\hline \multicolumn{10}{c}{ Chemical Composition, wt \% } \\
\hline $\mathbf{S i}$ & $\mathbf{C u}$ & $\mathbf{Z n}$ & $\mathbf{F e}$ & $\mathbf{M g}$ & $\mathbf{M n}$ & $\mathbf{N i}$ & $\mathbf{T i}$ & $\mathbf{C r}$ & $\mathbf{A l}$ \\
\hline $8.69-9.35$ & $2.09-2.43$ & $0.90-1.07$ & $0.82-0.97$ & $0.21-0.32$ & $0.18-0.25$ & $0.05-0.13$ & $0.042-0.049$ & $0.023-0.031$ & rest \\
\hline
\end{tabular}

The base alloy was melted in a gas-heated shaft furnace with a maximum charge capacity of 1.5 tonnes (StrikoWestofen, Gummersbach, Germany). After smelting, it was refined inside the shaft furnace. An Ecosal Al 113S solid refiner was used for this treatment. After tapping the alloy from the furnace into a ladle, it was deslagged with an Ecremal N44 deslagging agent. After deslagging, the liquid alloy was transferred to a holding furnace set up next to an Idra 700S horizontal cold chamber 
pressure die casting machine (Idra, Travagliato, Italy). In the holding furnace, AlCr15, AlMo8, AlV10 and AlW8 master alloys were added into the alloy. The temperature in the holding furnace was $750{ }^{\circ} \mathrm{C}$. After dissolution of the master alloys, the temperature of the liquid metal was reduced to a value appropriate for the test casting process. High melting point elements, i.e., chromium, molybdenum, vanadium and tungsten, were added as single elements, in double combinations (CrMo, CrV, CrW, $\mathrm{MoV}, \mathrm{MoW}$ and VW), in triple combinations (CrMoV, CrMoW, CrVW and MoVW), or all the additives were added simultaneously. For individually added $\mathrm{Cr}, \mathrm{Mo}, \mathrm{V}$ and $\mathrm{W}$, their content was kept in the range of $0.0-0.5 \mathrm{wt} \%$, and it was increased in $0.1 \mathrm{wt} \%$ steps. If more than one high melting point element was added, all the elements were used in equal amount. For double combinations, the content of additives was in the range of $0.0-0.4 \mathrm{wt} \%$, and in subsequent melts it was increased in $0.1 \mathrm{wt} \%$ steps. In the case of triple and quadruple combinations, the content of elements was in the range of $0.00-0.25 \mathrm{wt} \%$, and in subsequent melts it was increased in $0.05 \mathrm{wt} \%$ steps. From the resultant alloys, covers of roller shutter housings with a predominantly $2 \mathrm{~mm}$ wall thickness were made by the high pressure die casting process.

For each chemical composition tested, three specimens were taken from one high pressure die casting to carry out the tensile test. The specimens had a flat shape and $2 \times 10 \mathrm{~mm}^{2}$ rectangular cross-section. This cross-section is recommended by PN-EN 1706 standard for testing the strength of high pressure die casting. An Instron 3382 machine (Instron, Norwood, MA, USA) was used to perform the tensile test at a speed of $1 \mathrm{~mm} / \mathrm{min}$. The test enabled the determination of the tensile strength $R_{m}$, the yield strength $R_{\mathrm{p} 0.2}$ and the elongation A. Alloy hardness was measured by the Brinell method using an HPO-2400 hardness tester (WPM LEIPZIG, Leipzig, Germany) according to PN EN ISO 6506. The diameter of the ball was $2.5 \mathrm{~mm}$, the load was $613 \mathrm{~N}$, and the static load holding time was $30 \mathrm{~s}$.

Thermal and derivative analysis was used as a tool to study the solidification process. Thermal and derivative curves were recorded with a PtRh10-Pt thermocouple enclosed by a quartz tube placed in the thermal center of a probe made of a resin coated sand. Its dimensions are shown in Figure 1. The alloy was superheated to $1000{ }^{\circ} \mathrm{C}$ before the probe was filled with liquid alloy.

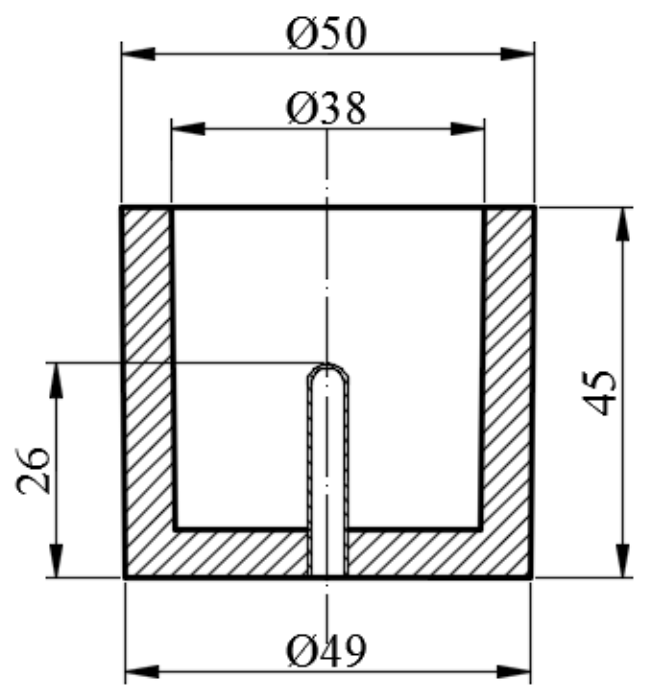

Figure 1. Dimensions of the resin coated sand probe (units: $\mathrm{mm}$ ).

Metallographic specimens for microstructure examinations were prepared on specimens taken from castings made in the resin coated sand probe and by high pressure die casting. The surface of the specimens was etched with a $2 \% \mathrm{HF}$ acid solution. The microstructure was examined using Nikon Eclipse MA200 optical microscope (Nikon, Tokyo, Japan) with $\times 100$ and $\times 1000$ magnification for castings made in the resin coated sand probe and by high pressure die casting process, respectively. The applied magnification ensures correct visibility of all alloy phases in the examined area. 
Point microanalysis of the element concentration was performed using the Pioneer EDS detector cooperating with the HITACHI S-3000N scanning electron microscope (Hitachi, Tokyo, Japan) and the VENTAGE software from NORAN. The specimens for scanning under the scanning microscope were cut from the test castings using a hand hacksaw and water cooling. The shell mold casting specimens had the shape of a cube with a side of $10 \mathrm{~mm}$. Specimens taken from high pressure die castings had the shape of a cuboid with sides $2 / 10 / 20 \mathrm{~mm}$, and after cutting they were mounted in a conductive phenolic resin. After mounting, the specimen was cylindrical with a diameter of $36 \mathrm{~mm}$ and a height of $12 \mathrm{~mm}$. The specimens were then ground using sandpaper and polished using diamond suspensions with a gradation of 9 to $1 \mu \mathrm{m}$.

The area of the spot examination of the elements concentration is shown in the figures of the microstructure made with the use of a scanning microscope. These images show the intermetallic phases within which the analyzes were performed. For the purpose of this study, phase precipitations of relatively large sizes were selected in order to avoid the analytical beam going beyond the area of the tested phase.

\section{Results and Discussion}

Figure 2 compares the thermal and derivative analysis curves of the EN AC-46000 base alloy and alloy containing $0.5 \mathrm{wt} \% \mathrm{Mo}$ and $\mathrm{Cr}, \mathrm{Mo}, \mathrm{V}$ and $\mathrm{W}$ added in an amount of $0.25 \mathrm{wt} \%$ each.

Studies have revealed a three-stage solidification process of the base EN EN-46000 alloy from the resin coated sand probe. The first stage taking place at the highest temperature is the crystallization of $\alpha(\mathrm{Al})$ dendrites solid solution. This process is marked by the thermal effect $\mathrm{C}_{\mathrm{s}} \mathrm{AB}$. The primary crystallization of $\alpha(\mathrm{Al})$ dendrites directly from the liquid results from Al-Si phase diagram shown in Figure 3.

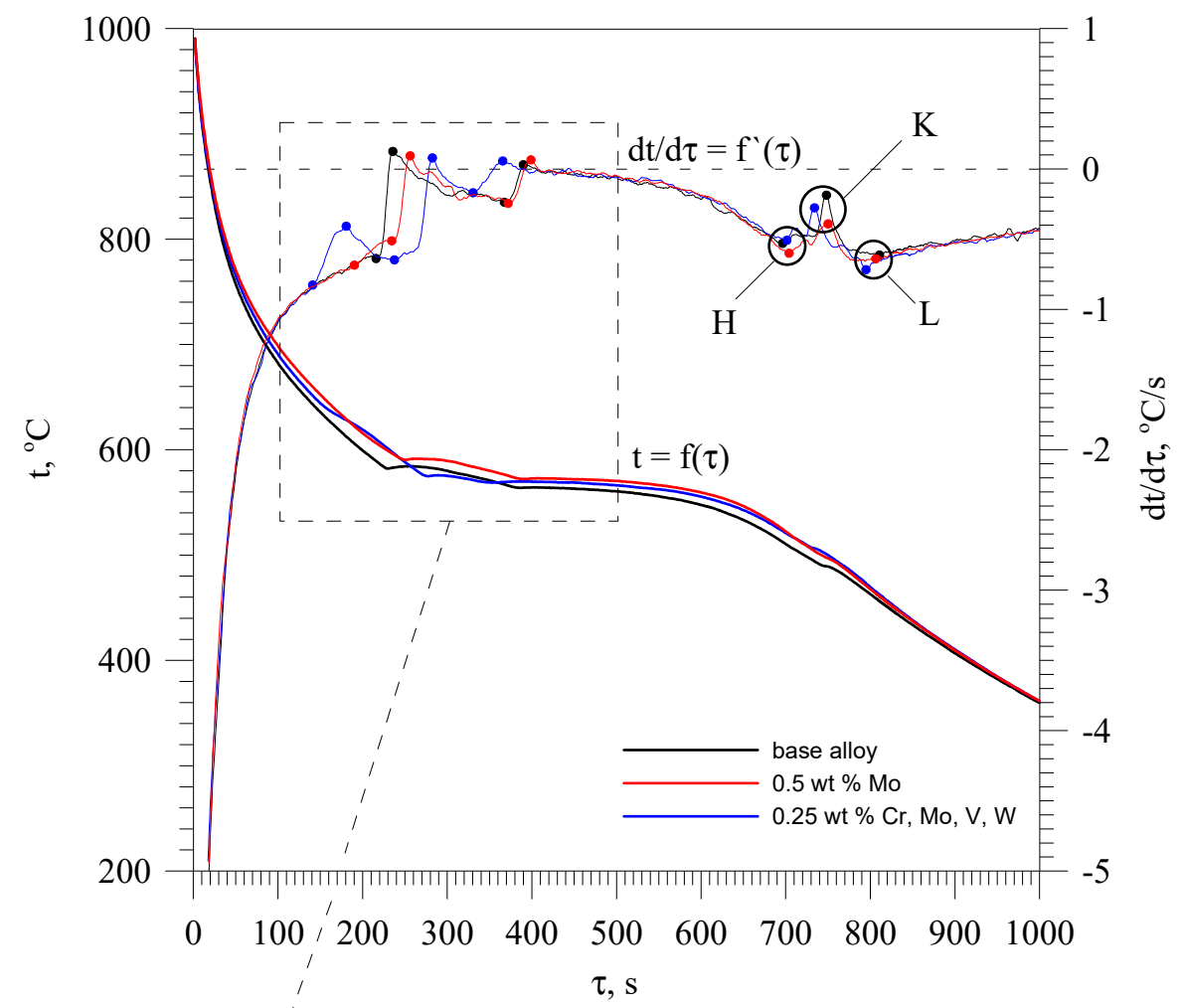

(a)

Figure 2. Cont. 


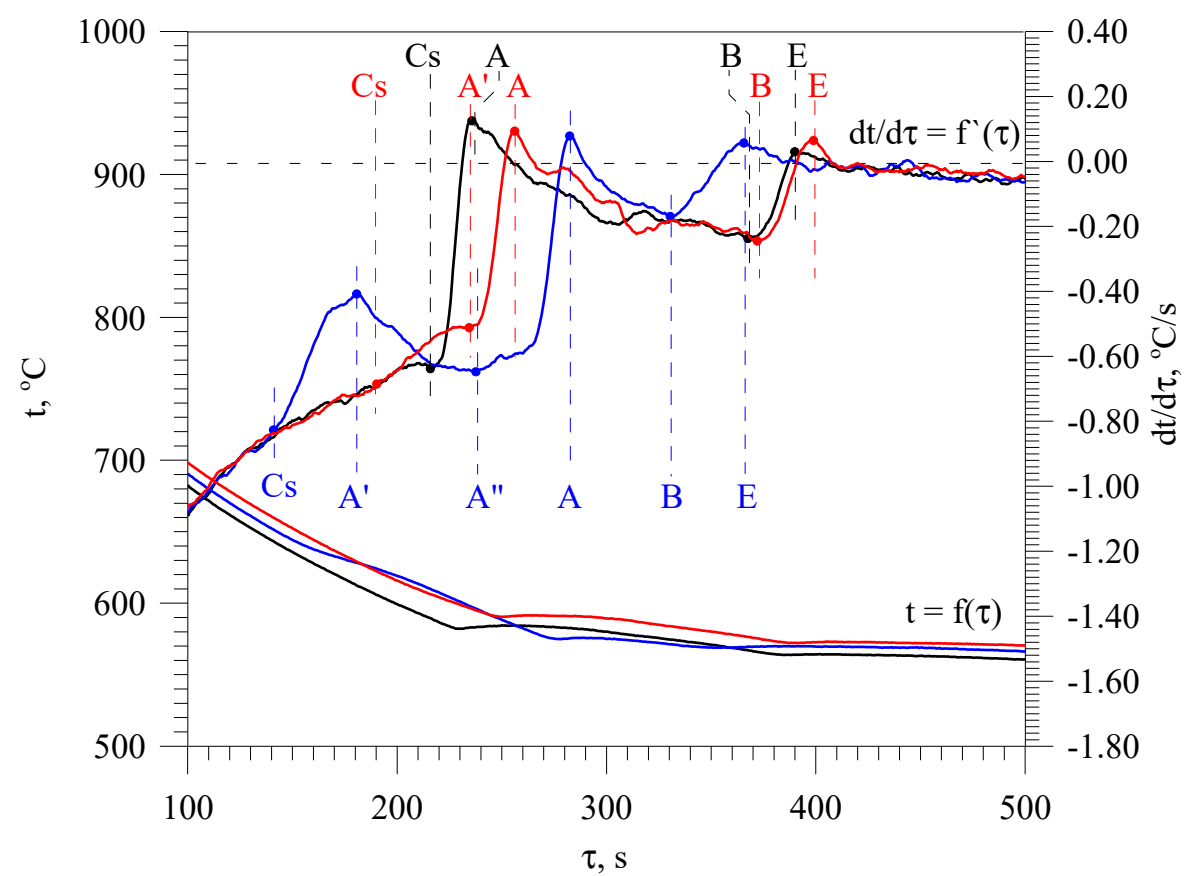

(b)

Figure 2. Thermal and derivative curves of the base alloy (black), alloy containing $0.5 \mathrm{wt} \% \mathrm{Mo}$ (red) and alloy containing $\mathrm{Cr}, \mathrm{Mo}, \mathrm{V}$ and $\mathrm{W}$ in an amount of $0.25 \mathrm{wt} \%$ each (blue). (a) and their enlarged fragment (b).

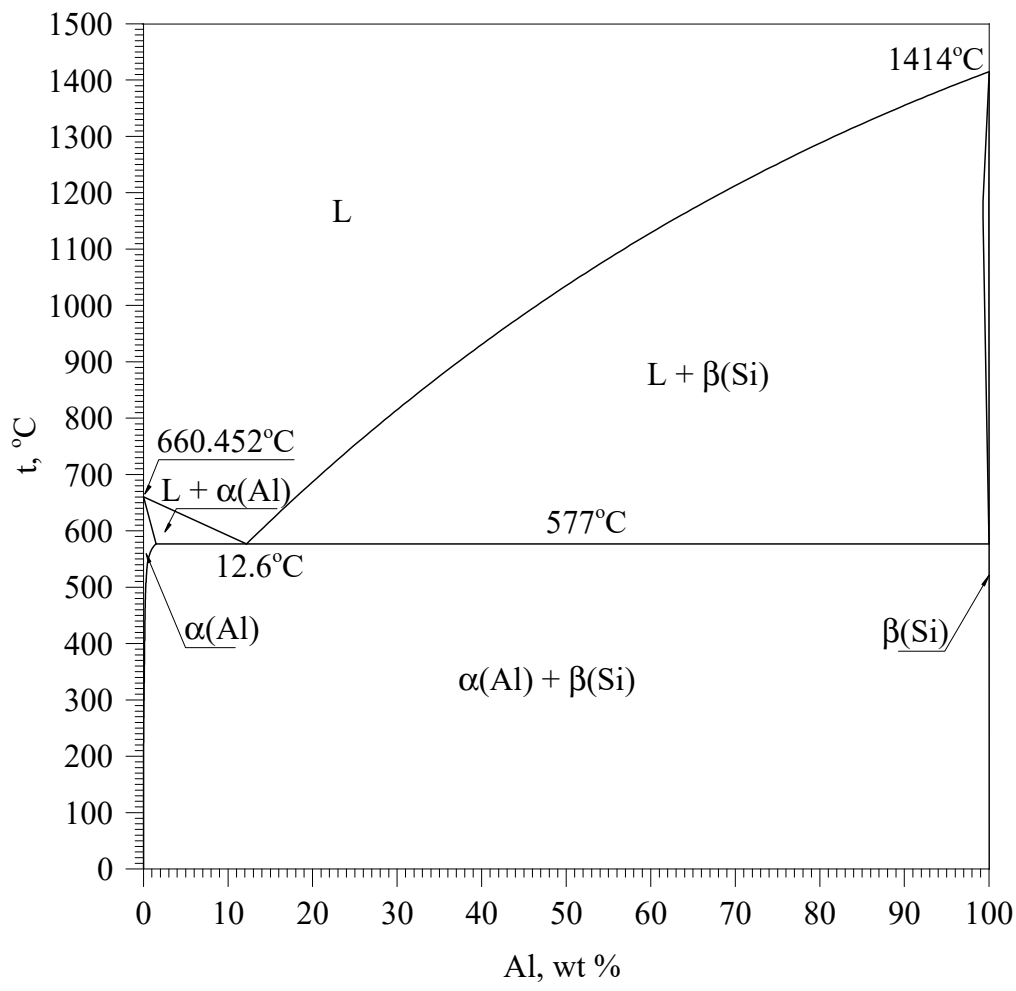

Figure 3. Al-Si phase diagram (data from [11,21,22]).

The presented Al-Si phase diagram shows that after the crystallization of $\alpha(\mathrm{Al})$ dendrites, the crystallization of $\alpha(\mathrm{Al})+\beta(\mathrm{Si})$ eutectic mixture takes place. The tested AlSi9Cu3(Fe) alloy is 
multicomponent, therefore more complex eutectic mixtures crystallize in it. In these mixtures, apart from $\alpha(\mathrm{Al})$ and $\beta(\mathrm{Si})$ phases, there are also intermetallic phases. The crystallization of multicomponent Al-Si alloys with this type of complex eutectic mixtures was described in detail in [22-24]. In accordance with the knowledge contained therein, the authors present the further crystallization process of the analyzed alloy.

When dendrite crystallization is complete, the complex $\alpha(\mathrm{Al})+\mathrm{Al}_{15}(\mathrm{Fe}, \mathrm{Mn})_{3} \mathrm{Si}_{2}+\beta(\mathrm{Si})$ (ternary) and $\alpha(\mathrm{Al})+\mathrm{Al}_{2} \mathrm{Cu}+\mathrm{AlSiCuFeMnMgNi}+\beta(\mathrm{Si})$ (quaternary) eutectic mixtures crystallize. Thermal effects caused by the crystallization of the above mentioned eutectic mixtures have been marked with the symbols BEH and HKL, respectively. The designation of AlSiCuFeMnMgNi phase should be treated as conventional, because it does not mean an intermetallic phase containing all the elements included, but a number of phases that may contain these elements. The chemical composition of this phase depends on the diversified (as a result of microsegregation) content of elements in different areas of the residual liquid. It can be $\mathrm{Mg}_{2} \mathrm{Si}$ phase or the phases from Al-Cu-Ni, Al-Fe-Mn-Si and Al-Cu-Mg-Si systems. The microstructure of the base alloy and containing $\mathrm{Cr}, \mathrm{Mo}, \mathrm{V}$ and $\mathrm{W}$ is presented in detail in [25]. This paper presents only those aspects of microstructure formation that are related to the mechanism of its strengthening presented by the authors.

When the additives in an amount not exceeding $0.1 \mathrm{wt} \% \mathrm{Cr}, 0.4 \mathrm{wt} \%$ Mo or $\mathrm{W}$, and $0.5 \mathrm{wt} \%$ $\mathrm{V}$ are added as single elements into the base alloy, there are no new thermal effects on the thermal and derivative curves and new phases are not formed in the microstructure. In this range of the content, the above mentioned elements tend to join the phases already existing in the base alloy. These are mainly iron-rich intermetallic phases occurring in both eutectic mixtures, designated as $\mathrm{Al}_{15}(\mathrm{Fe}, \mathrm{Mn}, \mathrm{M})_{3} \mathrm{Si}_{2}$, where $\mathrm{M}$ is any high melting point element or any combination of them. A single addition of chromium in an amount of $0.2 \mathrm{wt} \%$ and molybdenum or tungsten in an amount of $0.5 \%$ leads to primary crystallization of the $\mathrm{Al}_{15}(\mathrm{Fe}, \mathrm{Mn}, \mathrm{M})_{3} \mathrm{Si}_{2}$ phase. Vanadium in the tested content range did not cause this phase to crystallize. As a result of the crystallization of the primary $\mathrm{Al}_{15}(\mathrm{Fe}, \mathrm{Mn}, \mathrm{M})_{3} \mathrm{Si}_{2}$ phase on the derivative curve a thermal effect is created, which does not have a distinct local maximum. An example of such an effect is visible on the derivative curve of an alloy containing 0.5 wt \% Mo (Figure 2-red color) and is described as $\mathrm{C}_{\mathrm{s}} \mathrm{A}^{\prime}$. Increasing the amount of high melting point elements produces a thermal effect with a clearly visible local maximum. This thermal effect is shown in Figure 2 (blue color), for an alloy containing $0.25 \mathrm{wt} \% \mathrm{Cr}, \mathrm{Mo}, \mathrm{V}$ and $\mathrm{W}$. It is described as $\mathrm{C}_{\mathrm{s}} \mathrm{A}^{\prime} \mathrm{A}^{\prime \prime}$. The amount and size of this phase increases with the increase in the content of high melting point elements in the alloy. Figure 4 shows the microstructure of the base alloy and containing $0.25 \mathrm{wt} \% \mathrm{Mo}, \mathrm{V}$ and $\mathrm{W}$ each with marked component phases.

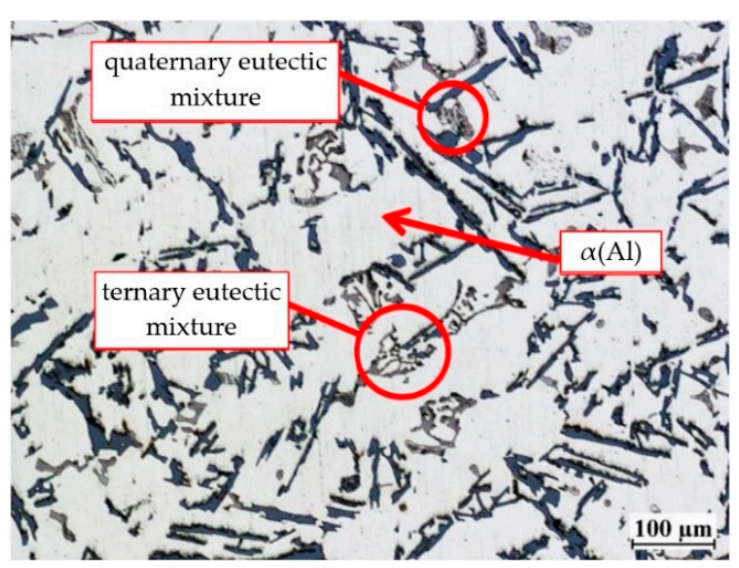

(a)

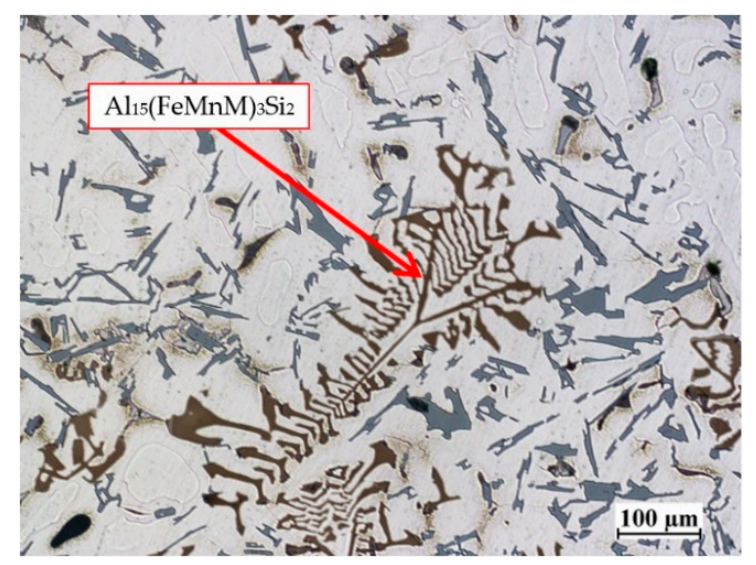

(b)

Figure 4. The microstructure of: (a) EN AC-AlSi9Cu3(Fe) base alloy, (b) alloy containing Mo, V and W in an amount of $0.25 \mathrm{wt}$. \% each. 
In Figure $4 \mathrm{~b} \mathrm{Al}{ }_{15}(\mathrm{Fe}, \mathrm{Mn}, \mathrm{M})_{3} \mathrm{Si}_{2}$ phase is characterized by a skeletal morphology. For example, Figure 5 shows the chemical composition of the analogous phase in the alloy containing $0.4 \mathrm{wt} \% \mathrm{Cr}$.

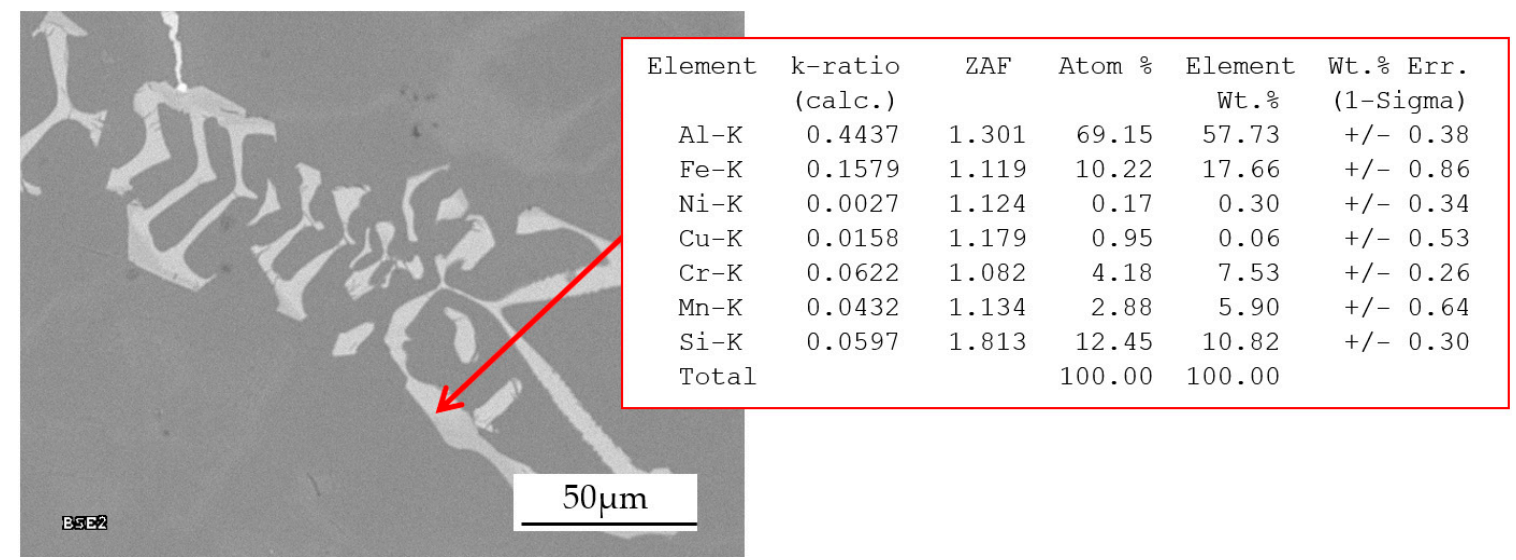

Figure 5. An example of the area with $\mathrm{Al}_{15}(\mathrm{Fe}, \mathrm{Mn}, \mathrm{M})_{3} \mathrm{Si}_{2}$ phase in the alloy containing $0.4 \mathrm{wt} \% \mathrm{Cr}$ from the shell mold and the results of the point measurement of the chemical composition within it.

There is a high concentration of $\mathrm{Al}(57.7 \mathrm{wt} \%)$ and an increased concentration of $\mathrm{Fe}(17.7 \mathrm{wt} \%)$ in the phase; $\mathrm{Si}(10.8 \mathrm{wt} \%) ; \mathrm{Cr}(7.53 \mathrm{wt} \%)$ and $\mathrm{Mn}(5.9 \mathrm{wt} \%)$. Its phase chemical composition indicates that it is $\mathrm{Al}_{15}(\mathrm{Fe}, \mathrm{Mn}, \mathrm{Cr})_{3} \mathrm{Si}_{2}$ phase. The occurrence of this phase in alloys containing $\mathrm{Cr}$ has been confirmed in [26-28]. The chemical analysis of $\mathrm{Al}_{15}(\mathrm{Fe}, \mathrm{Mn}, \mathrm{M})_{3} \mathrm{Si}_{2}$ phase detected in alloys containing additionally Mo, $\mathrm{V}$ and $\mathrm{W}$ showed the presence of all these elements. Thus, the crystallization of these intermetallics causes the depletion of the remaining liquid in high melting point elements. A relatively large amount of the primary $\mathrm{Al}_{15}(\mathrm{Fe}, \mathrm{Mn}, \mathrm{M})_{3} \mathrm{Si}_{2}$ phase causes the depletion of the liquid in high melting point elements leading to crystallization the classic plate $\alpha(\mathrm{Al})+\beta(\mathrm{Si})$ eutectic mixture instead of the ternary one. Thus, high melting point elements first increase their concentration ahead of the crystallization front of $\alpha(\mathrm{Al})$ phase, but then reduces it as a result of the primary crystallization of $\mathrm{Al}_{15}(\mathrm{Fe}, \mathrm{Mn}, \mathrm{M})_{3} \mathrm{Si}_{2}$ phase. The possibility of supersaturation of $\alpha(\mathrm{Al})$ dendrites is related to the concentration of the dissolved substance ahead of the dendrite crystallization front [29] and the rate of heat transfer during the solidification process. In [30,31], general relationships (1) and (2) were developed to link the crystal nucleation rate and growth rate, respectively, with the supersaturation of the crystal with the substance on the crystallization front:

$$
\begin{aligned}
& \mathrm{B}=\mathrm{k}_{\mathrm{b}} \times \Omega^{\mathrm{b}}, \\
& \mathrm{V}=\mathrm{k}_{\mathrm{v}} \times \Omega^{\mathrm{v}},
\end{aligned}
$$

where:

B-crystal nucleation rate,

V-crystal growth rate,

$\Omega$-supersaturation,

$\mathrm{k}_{\mathrm{b}}$ and $\mathrm{k}_{\mathrm{v}}$-original constant rate of crystal nucleation and growth, respectively,

and v-supersaturation exponent for crystal nucleation and growth, respectively.

From the above mentioned relationships it follows that an increase in the crystal nucleation rate and growth rate increases the degree of supersaturation. It is also generally known that that the higher rate of heat transfer leads to the higher rate of the nucleation and growth of the crystal. Therefore, two factors can accelerate supersaturation-a high concentration of high melting point elements on the dendritic crystallization front and the high rate of heat transfer during crystallization. Based on 84 thermal and derivative tests for the base alloy as well as all variants of the high melting point 
elements used, the average heat transfer rate during the crystallization of $\alpha(\mathrm{Al})$ phase was calculated. The value obtained was $0.13^{\circ} \mathrm{C} / \mathrm{s}$. This, relatively low, heat transfer rate in castings from shell molds creates rather modest possibilities of $\alpha(\mathrm{Al})$ supersaturation with high melting point elements. However, the extensive thermal and derivative tests showed an increase in the crystallization start temperature $\mathrm{C}_{\mathrm{s}}$ as a result of addition high melting point elements and increasing their content in the alloy. This was the case for all analyzed combinations of these elements. Figure 6 shows the effect of high-melting elements on the crystallization start temperature $\Delta \mathrm{tCs}$, for individually and simultaneously added $\mathrm{Cr}$, Mo, $\mathrm{V}$ and $\mathrm{W}$.

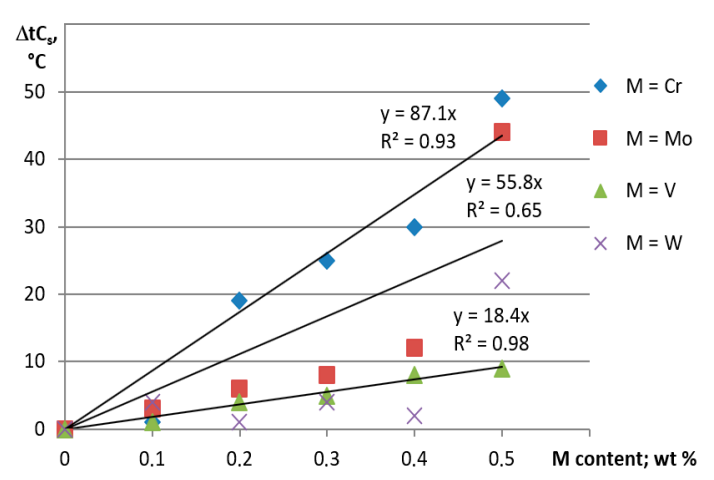

(a)

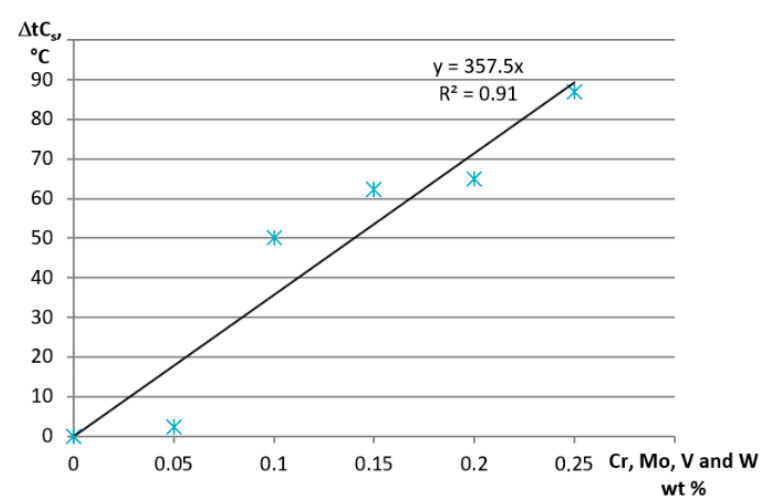

(b)

Figure 6. Changes in the crystallization temperature $\Delta t C_{s}$ caused by the variable content of $C r, M o$, $\mathrm{V}$ or $\mathrm{W}$ added: (a) as single elements and (b) jointly; $\mathrm{M}$-any high melting point element tested, i.e., $\mathrm{Cr}$, Mo, $\mathrm{V}$ or $\mathrm{W}$.

Figure 6a shows that all individually added high melting point elements increase the liquidus temperature. This is mainly due to the pre-dendritic crystallization of $\mathrm{Al}_{15}(\mathrm{Fe}, \mathrm{Mn}, \mathrm{M})_{3} \mathrm{Si}_{2}$ phase, which occurs when $0.2 \mathrm{wt} \% \mathrm{Cr}$ and $05 \mathrm{wt} . \% \mathrm{Mo}$ and $\mathrm{W}$ are added (thermal effects $\mathrm{C}_{\mathrm{s}} \mathrm{A}^{\prime}$ or $\mathrm{C}_{\mathrm{s}} \mathrm{A}^{\prime} \mathrm{A}^{\prime \prime}$ ). Crystallization of this phase is responsible for a rapid increase in the temperature $\Delta t C_{s}$. However, for each high melting point element analyzed, the increase in $\mathrm{C}_{\mathrm{s}}$ temperature was also obtained in the range of their concentration that did not cause pre-dendritic crystallization of $\mathrm{Al}_{15}(\mathrm{Fe}, \mathrm{Mn}, \mathrm{M})_{3} \mathrm{Si}_{2} \mathrm{Phase}$ This tendency is clearly visible when V, Mo and W are added. Vanadium did not cause pre-dendritic crystallization of $\mathrm{Al}_{15}(\mathrm{Fe}, \mathrm{Mn}, \mathrm{M})_{3} \mathrm{Si}_{2}$ phase, while Mo and $\mathrm{W}$ did not cause this phase to crystallize to $0.4 \mathrm{wt} \%$. In the above-mentioned range of high melting point elements, the increase of $\Delta \mathrm{tC}_{\mathrm{s}}$ is relatively mild. When Cr, Mo, V and $\mathrm{W}$ are simultaneously added (Figure 6b), up to $0.05 \mathrm{wt} \%$ each, the increase in $\Delta \mathrm{tCs}$ is also initially mild, but starting with the $0.10 \mathrm{wt} \%$, a rapid jump and faster growth occur. This rapid increase in $\Delta \mathrm{tC}_{\mathrm{s}}$ is due to the pre-dendritic crystallization of the $\mathrm{Al}_{15}(\mathrm{Fe}, \mathrm{Mn}, \mathrm{M})_{3} \mathrm{Si}_{2}$ phase. The increase in the liquidus temperature at the content of high melting point elements insufficient to start the primary crystallization of $\mathrm{Al}_{15}(\mathrm{Fe}, \mathrm{Mn}, \mathrm{M})_{3} \mathrm{Si}_{2}$ phase indicates transfer of a certain amount of these elements to $\alpha(\mathrm{Al})$ dendrites. Much better conditions for supersaturation of the $\alpha(\mathrm{Al})$ solid solution with high melting point elements are provided by the high pressure die casting (HPDC) technology, where the rate of heat transfer from the casting is much higher. The rate of heat transfer during crystallization of the $\alpha(\mathrm{Al})$ dendrites in HPDC alloy was determined from relationship (3) presented in [32]:

$$
\mathrm{SDAS}=39.4 \times \mathrm{V}^{\wedge}(-0.317)
$$

where:

SDAS-secondary dendrite arms spacing in $\alpha(\mathrm{Al})$ phase, $\mu \mathrm{m}$;

$\mathrm{V}$-the rate of heat transfer during the crystallization of $\alpha(\mathrm{Al})$ dendrites, ${ }^{\circ} \mathrm{C} / \mathrm{s}$.

The measured average SDAS in the examined HPDC alloy was $10.65 \mu \mathrm{m}$. The rate of heat transfer calculated for SDAS from relationship (3) amounts to $\sim 55^{\circ} \mathrm{C} / \mathrm{s}$. This value is over 400 times higher 
than the value obtained for alloy from shell mold. The high rate of heat transfer from the HPDC alloy produces more refined microstructure compared with the microstructure obtained in shell mold. Figure 7 shows the microstructure of HPDC EN AC-46000 alloy containing Cr, V and W, each in an amount of $0.25 \mathrm{wt} \%$. The constituent phases are also marked.

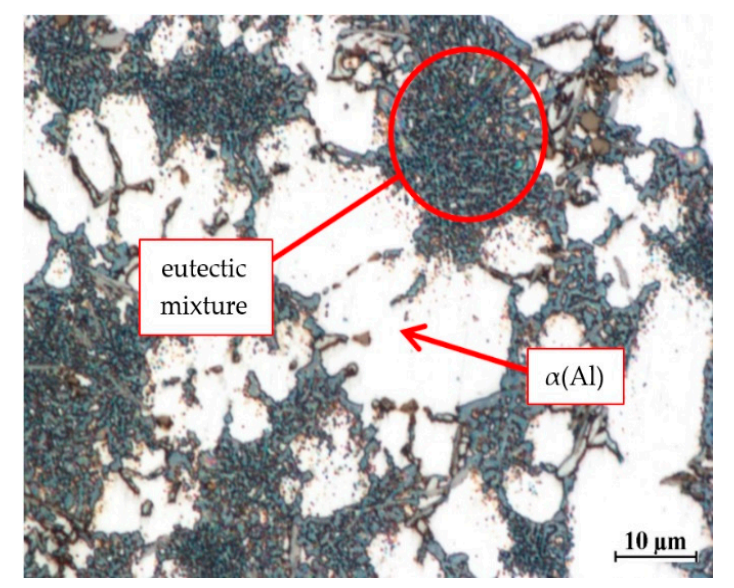

(a)

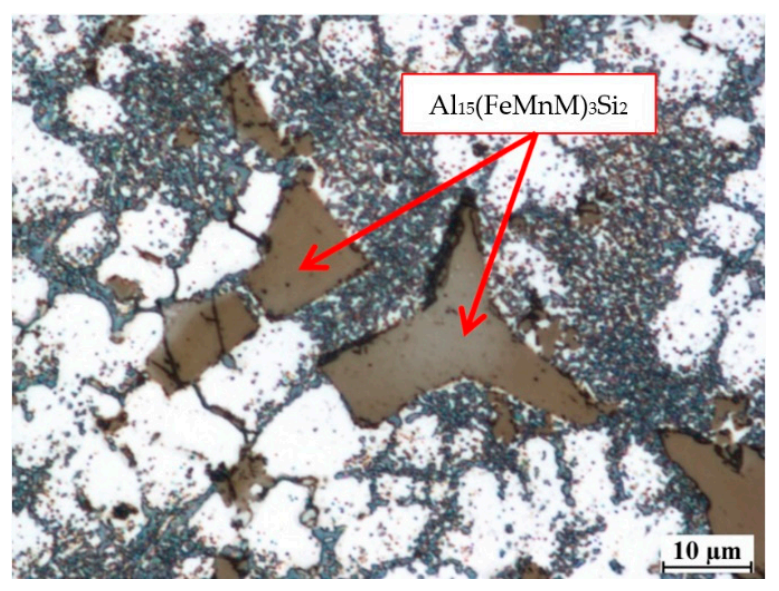

(b)

Figure 7. The microstructure of: (a) base alloy and (b) alloy containing $\mathrm{Cr}, \mathrm{V}$ and $\mathrm{W}$ in an amount of 0.25 wt $\%$ each.

The microstructure of the die cast base alloy consists of $\alpha(\mathrm{Al})$ phase dendrites and eutectic mixture. The eutectic mixture consists of $\alpha(\mathrm{Al})$ and $\beta(\mathrm{Si})$ solid solutions and relatively fine intermetallic phases. Diffraction tests have shown the presence of intermetallic phases: $\mathrm{Al}_{2} \mathrm{Cu}, \mathrm{Al}_{2} \mathrm{CuMg}$ and other phases that crystallize in Al-Fe-Si, Al-Cu-Fe and Mn-Ni-Si phase systems. The addition of a certain amount of high melting point elements causes the pre-dendritic crystallization of the $\mathrm{Al}_{15}(\mathrm{Fe}, \mathrm{Mn}, \mathrm{M})_{3} \mathrm{Si}_{2}$ phase. With the increasing content of above mentioned elements, the amount of this phase also increases. Figure $7 \mathrm{~b}$ shows this phase assume the form of polygons or stars. The size of the precipitates, depending on the content of high melting point elements, is from a few to $\sim 50 \mu \mathrm{m}$. Analysis of the chemical composition of the pre-dendritic $\mathrm{Al}_{15}(\mathrm{Fe}, \mathrm{Mn}, \mathrm{M})_{3} \mathrm{Si}_{2}$ phase has shown that it can "assimilate" all high melting point elements tested. Figure 8 presents the results of EDS point analysis carried out within the area of the pre-dendritic phase in the alloy containing $\mathrm{Cr}, \mathrm{Mo}, \mathrm{V}$ and $\mathrm{W}$ in an amount of $0.25 \mathrm{wt} . \%$ each.

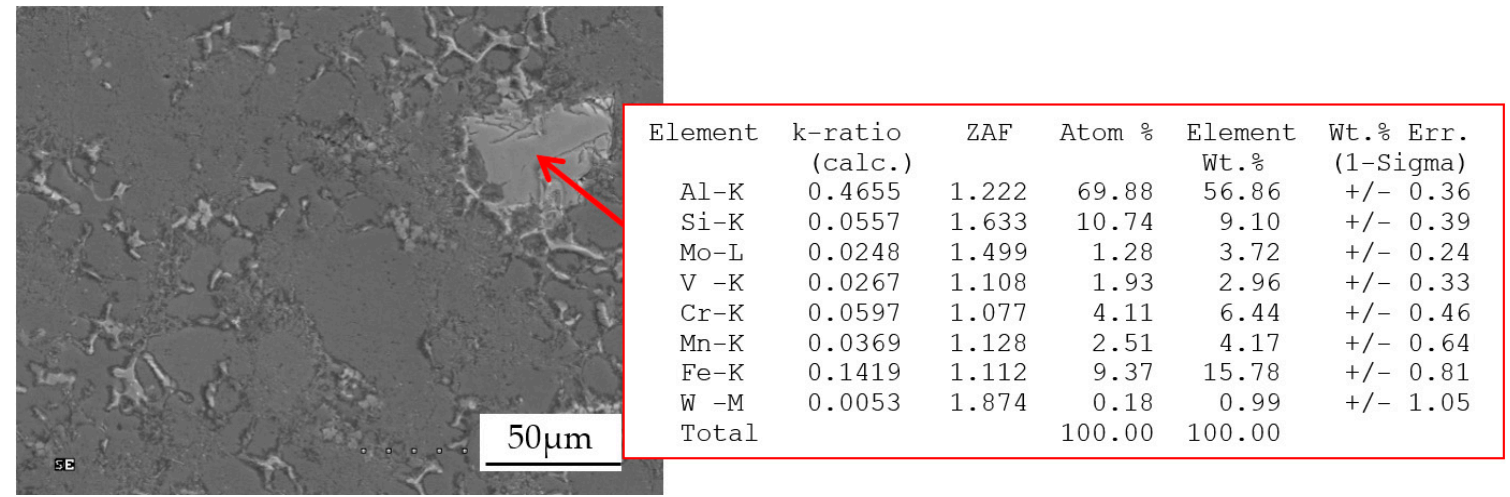

Figure 8. An example of $\mathrm{Al}_{15}(\mathrm{FeMnM})_{3} \mathrm{Si}_{2}$ phase in $\mathrm{HPDC}$ alloy containing $\mathrm{Cr}, \mathrm{Mo}, \mathrm{V}$ and $\mathrm{W}$ in an amount of $0.25 \mathrm{wt} \%$ each and the results of a point analysis of the chemical composition within it.

The EDS analysis shows that the tested phase is most effective in assimilating $\mathrm{Cr}(6.44 \mathrm{wt} \%)$, slightly less effective in Mo (3.72 wt \%) and V (2.96 wt \%), and the least effective in W (0.99 wt \%). The total concentration of $\mathrm{Cr}, \mathrm{Mo}, \mathrm{V}$ and $\mathrm{W}$ in this phase is $\sim 14 \mathrm{wt} \%$. The "assimilation" of chromium, 
molybdenum, vanadium and tungsten by the $\mathrm{Al}_{15}(\mathrm{Fe}, \mathrm{Mn}, \mathrm{M})_{3} \mathrm{Si}_{2}$ phase causes the depletion of these elements in the liquid. Since the $\mathrm{Al}_{15}(\mathrm{Fe}, \mathrm{Mn}, \mathrm{M})_{3} \mathrm{Si}_{2}$ phase crystallizes directly in front of the $\alpha(\mathrm{Al})$ dendrites, in the liquid ahead of the dendritic crystallization front, similar changes occur in the concentration of $\mathrm{Cr}, \mathrm{Mo}, \mathrm{V}$ and $\mathrm{W}$ as in the alloy from the shell mold. Chromium, molybdenum, vanadium and tungsten in the range of concentration that did not cause the pre-dendritic crystallization of $\mathrm{Al}_{15}(\mathrm{Fe}, \mathrm{Mn}, \mathrm{M})_{3} \mathrm{Si}_{2}$ phase leads to an increase in the concentration of these elements ahead of the crystallization front of $\alpha(\mathrm{Al})$ dendrites. Further increase in the content of above mentioned elements to a level that can trigger the crystallization of the pre-dendritic $\mathrm{Al}_{15}(\mathrm{Fe}, \mathrm{Mn}, \mathrm{M})_{3} \mathrm{Si}_{2}$ phase reduces the $\mathrm{Cr}, \mathrm{Mo}, \mathrm{V}$ and $\mathrm{W}$ concentration ahead of the crystallization front of $\alpha(\mathrm{Al})$ dendrites. The described changes in the concentration of $\mathrm{Cr}, \mathrm{Mo}, \mathrm{V}$ and $\mathrm{W}$ ahead of the crystallization front of $\alpha(\mathrm{Al})$ dendrites can significantly affect the mechanical properties of HPDC alloy. The relatively high cooling rate during the crystallization of $\alpha(\mathrm{Al})$ dendrites, $\left(\sim 55^{\circ} \mathrm{C} / \mathrm{s}\right)$, leads to supersaturation of the $\alpha(\mathrm{Al})$ phase with chromium, molybdenum, vanadium and tungsten, and may increase the mechanical properties of HPDC alloy. This is confirmed by the results of the statistical analysis of the effect of $\mathrm{Cr}$, Mo, $\mathrm{V}$ and $\mathrm{W}$ on the tensile strength $\mathrm{R}_{\mathrm{m}}$; yield strength $\mathrm{R}_{\mathrm{p} 0.2 \text {; }}$ elongation $\mathrm{A}$ and Brinell hardness of HPDC alloy presented in [33-35]. Statistical analysis was performed at the significance level $p(\alpha)=0.05$. The analysis of variance (ANOVA) test for the main effects was used to assess the influence of high melting point elements on the mechanical properties. The values of strength properties in [33-35] were presented in the standardized and dimensionless form. The results of the statistical analysis showed that each high melting point element can cause an increase in $\mathrm{R}_{\mathrm{m}}, \mathrm{R}_{\mathrm{p} 0.2} ; \mathrm{A}$ and $\mathrm{HB}$. The data presented in these papers shows an unambiguously analogous nature of the impact of the tested high melting point elements on the properties of this alloy. For the purposes of this paper, standardized quantities were decoded to the form of real values, which can be expressed in the units of measurement proper for the tested mechanical properties. Figure 9 presents an example of the effect of high melting point elements on the $R_{m}, R_{p 0.2} ; A$ and HB. The error bars shown in the graphs represent the values of the Standard Error of the Mean (SEM). The small SEM values shown in (Figure 9) prove the correctness of the results, which indicate the effect of high melting point elements on the tested properties.

Figure 9 a shows that $\mathrm{Cr}$ at the level of $0.05 \mathrm{wt} \%$ allows to obtain the tensile strength $\mathrm{R}_{\mathrm{m}}=274.4 \mathrm{MPa}$. It is a value by $\sim 13 \%$ higher in relation to the base alloy. Other high melting point elements make it possible to obtain a high $R_{\mathrm{m}}$ value with a content $0.05-0.10 \mathrm{wt} \% .0 .05 \mathrm{wt} \%$ vanadium has the greatest effect on the increase in $R_{m}$. This elements results in $R_{m}=277 \mathrm{MPa}$, which means an increase by $\sim 14 \%$ relative to the base alloy.

The highest yield strength is obtained with the addition of high melting point element in an amount of $0.05 \mathrm{wt} \%$. The element most effective in increasing the value of $R_{\mathrm{p} 0.2}$ is vanadium (Figure $9 \mathrm{~b}$ ). Its presence produces $R_{\mathrm{p} 0.2}=126.8 \mathrm{MPa}$, which means an increase by $\sim 12 \%$ relative to the base alloy. The highest elongation is usually obtained when the amount of high melting point element is $0.15 \mathrm{wt}$ $\%$. The greatest impact on the increase in elongation has $0.15 \mathrm{wt} \%$ Mo. The elongation is then $5.30 \%$, which gives a $40 \%$ increase relative to the base alloy. The data presented in Figure $9 \mathrm{c}$ shows that chromium in an amount of $0.15 \mathrm{wt} \%$ is also very effective in increasing the elongation to $\mathrm{A}=5.21 \%$. Relative to the base alloy, it is a $36 \%$ increase.

To obtain high values of the Brinell hardness, the optimal content of high melting point elements is $0.05 \mathrm{wt} \%$ for chromium, molybdenum and vanadium, and $0.5 \mathrm{wt} \%$ for tungsten. The impact of $\mathrm{V}$ and $\mathrm{W}$ on HB levels is shown in Figure 9d. The greatest impact on HB increase has $0.5 \mathrm{wt} . \% \mathrm{~W}$ $(117 \mathrm{HB})$. The relative increase is rather small and amounts to $5 \%$. 


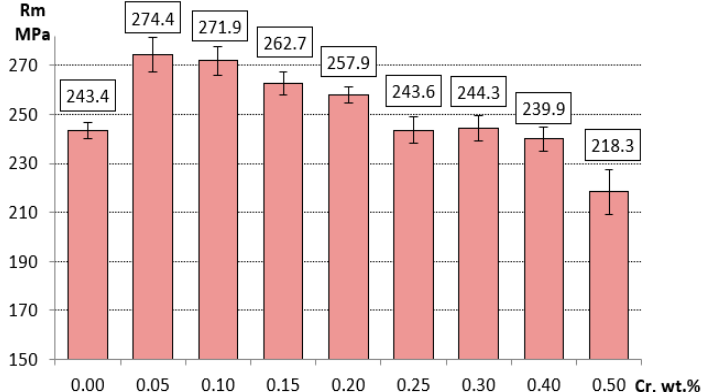

(a)

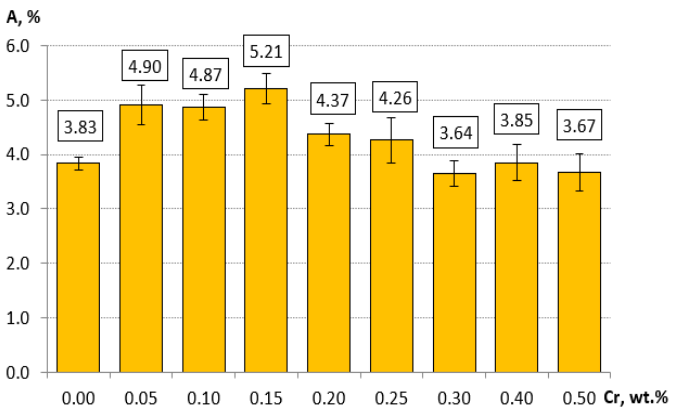

(c)

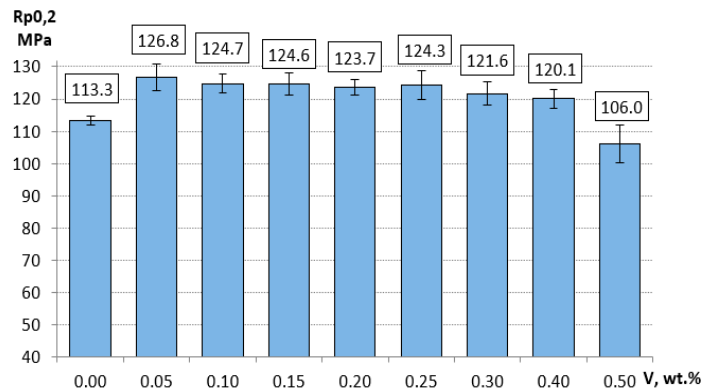

(b)

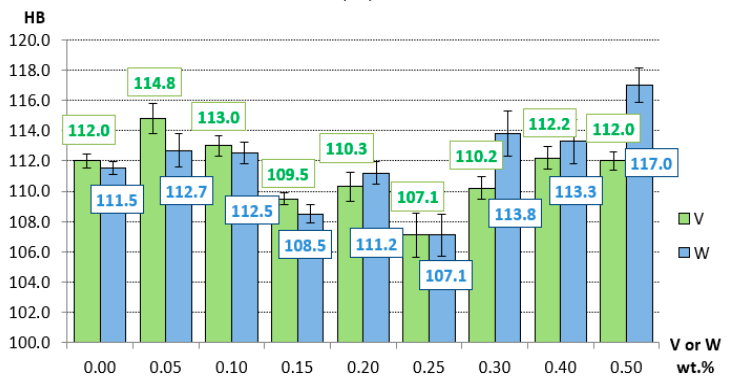

(d)

Figure 9. Examples of the effect of selected high melting point elements on the mechanical properties: (a) the effect of $\mathrm{Cr}$ on $\mathrm{R}_{\mathrm{m}}$ level; (b) the effect of $\mathrm{V}$ on $\mathrm{R}_{\mathrm{p} 0.2}$ level; (c) the effect of $\mathrm{Cr}$ on A level, (d) the effect of $\mathrm{V}$ and $\mathrm{W}$ on $\mathrm{HB}$ level.

The highest values of $R_{m}$ and $R_{p 0.2}$ are the result of a relatively high supersaturation of $\alpha(\mathrm{Al})$ solid solution with these elements. The effect of this phenomenon on the strength properties is most beneficial, when the high melting point elements are added in an amount insufficient to start the primary crystallization of $\mathrm{Al}_{15}(\mathrm{Fe}, \mathrm{Mn}, \mathrm{M})_{3} \mathrm{Si}_{2}$ phase. The supersaturation of $\alpha(\mathrm{Al})$ dendrites is also beneficial for the hardness of alloy containing $0.05 \mathrm{wt} \% \mathrm{Cr}$, Mo or V. The highest hardness obtained at $0.5 \mathrm{wt} \%$ $\mathrm{W}$ was due to the presence of relatively large precipitates of $\mathrm{Al}_{15}(\mathrm{Fe}, \mathrm{Mn}, \mathrm{W})_{3} \mathrm{Si}_{2}$ phase. The largest increase in elongation accompanying the addition of high melting point elements in an amount of $0.15 \mathrm{wt} \%$ was the result of primary crystallization of relatively small and compact precipitates of $\mathrm{Al}_{15}(\mathrm{Fe}, \mathrm{Mn}, \mathrm{M})_{3} \mathrm{Si}_{2}$ phase, which reduced the concentration of high melting point elements as well as $\mathrm{Fe}$ and $\mathrm{Mn}$ ahead of the crystallization front of $\alpha(\mathrm{Al})$ dendrites. Crystallization of $\mathrm{Al}_{15}(\mathrm{Fe}, \mathrm{Mn}, \mathrm{M})_{3} \mathrm{Si}_{2}$ phase in alloy with high melting point elements can reduce the supersaturation of $\alpha(\mathrm{Al})$ dendrites compared with the alloy without them. This leads to an increase in the alloy plasticity.

Statistical analysis in [33-35] gives no evidence supporting the occurrence of a synergistic effect between simultaneously introduced high melting point elements and alloy properties. However, the results of mechanical tests carried out on various combinations of the co-introduced high melting point elements indicate the possibility of obtaining much higher values of $R_{m}, R_{p 0,2}$ and $A$ than the values obtained in a statistical analysis carried out for the same additives but introduced as single elements. The largest increase in $\mathrm{R}_{\mathrm{m}}$ was obtained with the addition of vanadium and tungsten added in an amount of approximately $0.2 \mathrm{wt} \%$ each. The value of $R_{m}$ was then $299 \mathrm{MPa}$, which means that it was higher by $\sim 50 \%$ relative to the base alloy. The same addition of $\mathrm{V}$ and $\mathrm{W}$ also caused the largest (over twofold) increase in an elongation. The maximum increase in $\mathrm{R}_{\mathrm{p} 0.2}$, i.e., by $\sim 21 \%$, was due to the use of $\mathrm{Cr}$ and $\mathrm{W}$ added in an amount of $0.1 \mathrm{wt} . \%$ each. 


\section{Conclusions}

From the data presented in this paper, the following conclusions emerge:

1. Proper amount of high melting point elements added into HPDC hypoeutectic alloy as well as alloy from shell molds results in pre-dendritic crystallization of the $\mathrm{Al}_{15}(\mathrm{Fe}, \mathrm{Mn}, \mathrm{M})_{3} \mathrm{Si}_{2}$ phase.

2. High intensity of the heat transfer during HPDC process enables supersaturation of $\alpha(\mathrm{Al})$ dendrites with high melting point elements.

3. The addition of $\mathrm{Cr}, \mathrm{Mo}, \mathrm{V}$ and $\mathrm{W}$ as well as pre-dendritic crystallization of the $\mathrm{Al}_{15}(\mathrm{Fe}, \mathrm{Mn}, \mathrm{M})_{3} \mathrm{Si}_{2}$ phase change concentration of the above mentioned elements ahead of the crystallization front of $\alpha(\mathrm{Al})$ dendrites, resulting in its various supersaturation during HPDC process.

4. A significant increase in mechanical properties of the tested hypoeutectic alloys was obtained by supersaturation of the $\alpha(\mathrm{Al})$ phase with high melting point elements during HPDC process.

5. Changes in mechanical properties of the tested alloys were largely affected by supersaturation of the $\alpha(\mathrm{Al})$ phase, and also by the size of precipitates and content of the pre-dendritic $\mathrm{Al}_{15}(\mathrm{Fe}, \mathrm{Mn}, \mathrm{M})_{3} \mathrm{Si}_{2}$ phase.

6. In the future, to prove the correctness of the presented hypothetical mechanism of strengthening of HPDC alloy by supersaturation of $\alpha(\mathrm{Al})$ phase with high melting point elements, analyzes should be carried out to show the presence of these elements in $\alpha(\mathrm{Al})$ phase with their different contents.

Author Contributions: Conceptualization, T.S., G.G. and T.P.; methodology, T.S., G.G. and T.P.; software, L.K. and J.S.; validation, T.S. and G.G.; formal analysis, T.S., G.G. and J.S.; investigation, T.S. G.G., L.K. and M.G.; resources, T.S.; data curation, T.S.; writing—original draft preparation, T.S. and G.G.; writing-review and editing, T.S. and G.G.; visualization, T.S.; supervision, T.S. and G.G.; project administration, T.P.; funding acquisition, T.P. All authors have read and agreed to the published version of the manuscript.

Funding: This research received no external funding.

Conflicts of Interest: The authors declare no conflict of interest.

\section{References}

1. Li, Y.; Yang, Y.; Wu, Y.; Wei, Z.; Liu, X. Supportive strengthening role of Cr-rich phase on Al-Si multicomponent piston alloy at elevated temperature. Mater. Sci. Eng. A 2011, 528, 4427-4430. [CrossRef]

2. Kim, H.Y.; Han, S.W.; Lee, H.M. The influence of Mn and $\mathrm{Cr}$ on the tensile properties of A356-0.20Fe alloy. Mater. Lett. 2006, 60, 1880-1883. [CrossRef]

3. Farkoosh, A.R.; Chen, X.G.; Pekguleryuz, M. Dispersoid strengthening of a high temperature Al-Si-Cu-Mg alloy via Mo addition. Mater. Sci. Eng. A 2015, 620, 181-189. [CrossRef]

4. Elhadari, H.A.; Patel, H.A.; Chen, D.L.; Kasprzak, W. Tensile and fatigue properties of a cast aluminum alloy with Ti, Zr and V additions. Mater. Sci. Eng. A 2011, 528, 8128-8138. [CrossRef]

5. Mahta, M.; Ememy, M.; Daman, A.; Keyvani, A.; Campbell, J. Precipitation of Fe rich intermetallics in Crand Co-modified A413 alloy. Int. J. Cast. Met. Res. 2005, 18, 73-79. [CrossRef]

6. Timelli, G.; Bonollo, F. The influence of $\mathrm{Cr}$ content on the microstructure and mechanical properties of $\mathrm{AlSi}_{9} \mathrm{Cu}_{3}(\mathrm{Fe})$ die-casting alloys. Mater. Sci. Eng. A 2010, 528, 273-282. [CrossRef]

7. Mbuya, T.O.; Odera, B.O.; Ng'ang'a, P.S. Influence of iron on castability and properties of aluminium silicon alloys: Literature review. Int. J. Cast Met. Res. 2003, 16, 451-465. [CrossRef]

8. Lin, B.; Li, H.; Xu, R.; Xiao, H.; Zhang, W.; Li, S. Effects of Vanadium on Modification of Iron-Rich Intermetallics and Mechanical Properties in A356 Cast Alloys with 1.5 wt.\% Fe. J. Mater. Eng. Perform. 2019, 28, 475-484. [CrossRef]

9. Mrówka-Nowotnik, G. Intermetallic Phases Examination in Cast $\mathrm{AlSi}_{5} \mathrm{Cu} 1 \mathrm{Mg}$ and $\mathrm{AlCu}_{4} \mathrm{Ni}_{2} \mathrm{Mg}_{2} \mathrm{Aluminium}$ Alloys in As-Cast and T6 Condition. In Recent Trends in Processing and Degradation of Aluminium Alloys; Ahmad, Z., Ed.; IntechOpen: Rijeka, Croatia, 2011; pp. 19-40.

10. Okamoto, H. Al-Cr (Aluminum-Chromium). J. Phase Equilibria Diffus. 2008, 29, 111-112. [CrossRef]

11. Alloy Phase Diagrams. In ASM Handbook; ASM Intertional: Novelty, MO, USA, 1992; Volume 3.

12. Okamoto, H. Al-Mo (Aluminum-Molybdenum). J. Phase Equilibria Diffus. 2010, 31, 492-493. [CrossRef]

13. Okamoto, H. Si-V (Silicon-Vanadium). J. Phase Equilibria Diffus. 2010, 31, 409-410. [CrossRef] 
14. Okamoto, H. Mo-Si (Molybdenum-Silicon). J. Phase Equilibria Diffus. 2011, 32, 176. [CrossRef]

15. Guo, Z.; Yuan, W.; Sun, Y.; Cai, Z.; Qiao, Z. Thermodynamic Assessment of the Si-Ta and Si-W Systems. J. Phase Equilibria Diffus. 2009, 30, 564-570. [CrossRef]

16. Venkataraman, M.; Neumann, J.P. The Cr-Mo (Chromium-Molybdenum) System. Bull. Alloy Phase Diagr. 1987, 8, 216-220. [CrossRef]

17. Smith, J.F.; Bailey, D.M.; Carlson, O.N. The Cr-V (Chromium-Vanadium) System. Bull. Alloy Phase Diagr. 1982, 2, 469-473. [CrossRef]

18. Zheng, F.; Argent, B.B.; Smith, J.F. Thermodynamic Computation of the Mo-V Binary Phase Diagram. J. Phase Equilibria 1999, 20, 370-372. [CrossRef]

19. Okamoto, H. V-W (Vanadium-Tungsten). J. Phase Equilibria Diffus. 2010, 31, 324. [CrossRef]

20. Nagender Naidu, S.V.; Sriramamurthy, A.M.; Rama Rao, P. The Cr-W (Chromium-Tungsten) System. Bull. Alloy Phase Diagr. 1984, 5, 289-292. [CrossRef]

21. Murray, J.L.; McAlister, A.J. The Al-Si (Aluminum-Silicon) System. Bull. Alloy Phase Diagr. 1984, 5, 74-84. [CrossRef]

22. Pietrowski, S. Al-Si Alloys; Lodz University of Technology Publishing House: Lodz, Poland, 2001.

23. Belov, N.A.; Eskin, D.G.; Aksenov, A.A. Multicomponent Phase Diagrams: Applications for Commercial Aluminum Alloys; Elsevier: London, UK, 2005.

24. Glazoff, M.V.; Khvan, A.V.; Zolotorevsky, V.S.; Belov, N.A.; Dinsdale, A.T. Casting Aluminum Alloys; Elsevier: Oxford, UK, 2019.

25. Szymczak, T.; Gumienny, G.; Klimek, L.; Goły, M.; Pacyniak, T. Microstructural characteristics of AlSi9Cu3(Fe) alloy with high melting elements. Metals 2020, 10, 1278. [CrossRef]

26. Robles Hernández, F.C.; Sokolowski, J.H. Thermal analysis and microscopical characterization of Al-Si hypereutectic alloys. J. Alloy. Compd. 2006, 419, 180-190. [CrossRef]

27. Matejka, M.; Bolibruchova, D. Influence of Remelting AlSi9Cu3 Alloy with Higher Iron Content on Mechanical Properties. Arch. Foundry Eng. 2018, 18, 25-30.

28. Shabestari, S.G. The effect of iron and manganese on the formation of intermetallic compounds in aluminum-silicon alloys. Mater. Sci. Eng. A 2004, 383, 289-298. [CrossRef]

29. Chai, G.; Bäckerud, L.; Rolland, T.; Arnberg, L. Dendrite coherency during equiaxed solidification in binary aluminum alloys. Metall. Mater. Trans. A 1995, 26A, 965-970. [CrossRef]

30. Nývlt, J. Kinetics of nucleation in solutions. J. Cryst. Growth 1968, 3, 377-383.

31. Nemdili, L.; Koutchoukali, O.; Mameri, F.; Gouaou, I.; Koutchoukali, M.S.; Ulrich, J. Crystallization study of potassium sulfate-water system, metastable zone width and induction time measurements using ultrasonic, turbidity and 3D-ORM techniques. J. Cryst. Growth 2018, 500, 44-51. [CrossRef]

32. Wu, X.; Zhang, H.; Ma, Z.; Jia, L.; Zhang, H. Effect of Holding Pressure on Microstructure and Mechanical Properties of A356 Aluminum Alloy. J. Mater. Eng. Perform. 2018, 27, 483-491. [CrossRef]

33. Szymczak, T.; Szymszal, J.; Gumienny, G. Statistical methods used in the assessment of the influence of the Al-Si alloy's chemical composition on its properties. Arch. Foundry Eng. 2018, 18, 203-211.

34. Szymczak, T.; Szymszal, J.; Gumienny, G. Evaluation of the effect of the Cr, Mo, V and W content in an Al-Si alloy used for pressure casting on its proof stress. Arch. Foundry Eng. 2018, 18, 105-111.

35. Szymczak, T.; Szymszal, J.; Gumienny, G. Evaluation of the Effect of Cr, Mo, V and W on the Selected Properties of Silumins. Arch. Foundry Eng. 2018, 18, 77-82.

Publisher's Note: MDPI stays neutral with regard to jurisdictional claims in published maps and institutional affiliations.

(C) 2020 by the authors. Licensee MDPI, Basel, Switzerland. This article is an open access article distributed under the terms and conditions of the Creative Commons Attribution (CC BY) license (http://creativecommons.org/licenses/by/4.0/). 